\title{
POSI BOLA OF JAMI MOSQUE AS SPATIAL TRANSFORMATION SYMBOL
}

Received July 2 $2^{\text {nd }}, 2018$ | Accepted October 10 2019 | Available online December $20^{\text {th }} 2019$ | DOI : http://dx. doi.org/10.18860/iia.v5i4.5226 |

Moh. Sutrisno

Department of Architecture, Faculty of Science and Technology

Universitas Islam Negeri Alauddin

Makassar, Indonesia

moh.sutrisno@mail.ugm.ac.id

Sudaryono Sastrosasmito

Department of Architecture

Universitas Gadjah Mada

Indonesia

sudaryono_sastrosasmito@yahoo.com

\section{Ahmad Sarwadi}

Department of Architecture

Universitas Gadjah Mada

Indonesia

sarwadi@ugm.ac.id

\begin{abstract}
Palopo city space as the center of Tana Luwu cannot be separated from the significance of the oldest kingdom in South Sulawesi. The entry of the Islamic religion in Luwu was marked by the Jami Mosque, which is located at the zero points of Palopo city. The preservation of pre-Islamic heritage and after the entry of Islam in the present tends to not a dichotomy in two different meanings. The research is aimed to explore the semiotic meaning of the Jami Mosque, which has become an icon in Palopo City. The research used the ethnomethodology method within the framework of the semiotics paradigm to obtain contextual meaning as well as the application of a new approach in architecture semiotics study. The results show that the Jami Mosque keeps the complexity of meaning, which can be the foundation of conservation philosophy and planning of the built environment. The cosmos axis of Palopo city space and the territory of Luwu become the central point of religious civilization, especially in Islamic cosmology. The space transformation is represented by 'posi bola' (house pole). The symbolic 'posi bola' moves from the palace to the Jami mosque as the axis of Luwu space in the Islamic era. The horizontal slice of the pole has implications on the particular geometrical patterns of Luwu. The elements of structure and construction of buildings become a symbol of Islamic teachings.
\end{abstract}

\section{KEYWORDS:}

Semiotics, cosmos axis, posi bola, cosmology, space

\section{INTRODUCTION}

In a long time, it is difficult to know the concepts of building a form of an architectural heritage building. As a building unit, the architectural heritage is resistant to the occurrence of form transformations. Heritage buildings cannot be guaranteed that they continue to exist as well as at the beginning of construction due to natural factors. The elements of building materials are impermanent and tend to be replaced with new materials. Changes that reduce the authenticity resulting from the development of science and technology are also unavoidable. It seems that the physical form of the building will visually change. On the other hand, the heritage building concepts applied to new buildings tend not to appear physically, although many new forms of buildings are found similar to old buildings. The historic urban landscape is considered more persistent from changing times rather than building units [1].

Palopo city is one of the cities in South Sulawesi province, Indonesia; it is categorized as an ancient city. Based on the study and archaeological findings, Palopo represents the features and layout of the ancient city in the world. The concept of the ancient city of Islam, especially in the Middle East (Baghdad), made mosques and palaces become the center of the city
[2]. The layout of the city based on the humullah, which is independent and marked by the Jami mosque, which analogues with the temple and Meru mountain [3]. It is like axis mundi on cosmology concept in southeast-Asia. Ancient cities in southeast-Asia and China are recognized by the concept of cosmology that embodies the order of microcosm and macrocosm. The characteristics of the ancient city embraces the dichotomy aspects of Yin and Yang, holy and dirty. Until now, indigenous cosmology peoples in China are again defined by the social, political, economic and cultural in which tourism interacts directly with past cultural practices for contemporary society [4].

Luwu people's knowledge of space cosmology related to the history of their ancestors, namely Tomanurung, Sawerigading, and I La Galigo. History also described the struggle of Sawerigading arrived in China. Sureq I La Galigo recounted the life of Luwu, which was very popular in the literature, and its content was longer than Mahabarata. But, all the contents of the I La Galigo manuscript told about preIslamic civilization.

People in Palopo city majority convert to Islam and the rest of them are Christians and Buddhists. There is also a belief in supernatural forces, the magical power of the heirlooms, and the power of gods [5]. 
Inside the Jami Mosque building, some objects are once believed to have magical powers, and the building is included in the heritage buildings of Palopo city. Pray suffers no calamity is done every Friday morning in the back yard of the mosque. The tradition of praying suffers no calamity is a hereditary activity that still maintained by religious leaders of the Jami Mosque.

The contemporary era building that fills Palopo city space has a different shape to the old buildings. The mayor's office building applies the classic style by adding a dome shape at the top of the office. The discussion was organized by Bapedda Palopo city in 2017 entitled "reading the symbol and identity of Palopo City space." The researcher noted from the discussion that the mayor's office was interpreted that it does not represent local wisdom. The community criticized scientific discussion forums conducted by Palopo urban forum after the design of the built environment because it tends to be non-contextual. The scientific study entitled Tana Luwu and Toraja Heritage Seminar 2017, where there was one of the keynote speakers who also highlighted the reality of contemporary building in Palopo city. Society has not met the intersection of what building becomes the symbol and identity of Palopo city, or the identity of the city is not a physical building, but the concepts are intangible. Explicit images of building icons are evidenced by the form of a city government logo that takes the Jami Mosque as the only architectural object that fills the logo elements. The reverse is that the Mayor's office is a role model for the surrounding buildings. The Mayor's office fills the Tana Bangkala area which is considered as sacred space. In this context that an old mosque building with distinctive architecture, the material used unlike in other buildings and it only one in South Sulawesi, tends to get dominant recognition as iconic architecture works.

Like other cities in Indonesia, commerce activities become one of the factors of foreigners' entry. Tionghoa ethnic civilization bequeaths history in filling civilization Palopo City space. There was acculturation with local culture since Arabs and Chinese people arrived in Palopo. Fung Man Te, the name of a stranger known to the people of Palopo because of his services as an architect of the Jami Mosque and his name is indexed inside the Jami Mosque. Jami Mosque is a mixture of various cultures from the middle-east, Hindu, Javanese and local cultures (Bugis) seen in architectural works that are valued [6]

The definition of Posi Bola is the center of the house, then the connotative meaning of posi bola is the center of Luwu sub-ethnicity located in the old Jami mosque. The meaning of the middle pole of the Jami mosque becomes the central symbol (posi) of the twelve Luwu tribes since the Islamic era. The middle pole represents the center of the Luwu area in the midst of 'ana tellu' Luwu kedatuan, i.e., Madika Bua, Madika Ponrang, and Makole Baebunta. Before Islam, the symbol of the central Luwu was in the royal palace called 'Langkanae' in the form of a large traditional house. A change followed the change in ideology from pre-Islam to Islam in the symbol of the cosmos axis from the palace to the Jami mosque. Until the end of research in 2018, Luwu center is represented by the Jami Mosque, especially the middle pillar of the mosque as a symbol of the center of Luwu house, which is also called 'Posi Bola'.

Posi tana or center of the earth is occupied by the Mallinoe Gods [7]. The macro coverage of the territory space that Tana Luwu is posi Tana and Mecca is called Palisu Tana [8]. The map that the position of Tana Luwu as a kingdom territory is at the center of the world or the earth.

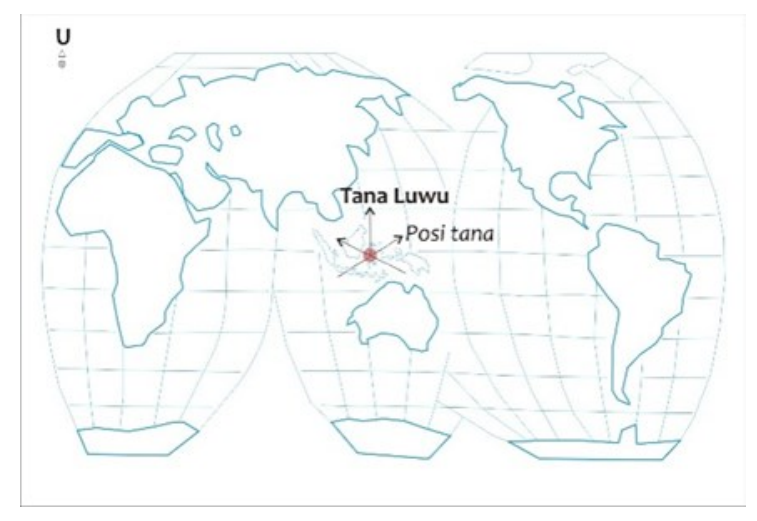

Figure 1. Location of Tana Luwu in the World Map

The issue of territory as a tagline was important because it would be easy to remember, so it tends to be an icon. The center of the archipelago became a landmark of duplication when Luwu Raya expanded into a province. Meanwhile, the center point of Indonesia has been represented by the city of Makassar as the capital of South Sulawesi. Based on preliminary studies, it is known that the location of the Jami Mosque signifier zero kilometers of Palopo city or Luwu Raya. The location of Palopo city is in the middle of the Luwu area so that the central position provides a strategic and balance function for the whole of Luwu.

Previous researchers such as Surur, Mahmud, Pawiloy, and researchers on other Palopo cities, there was none of them explained the architectural aspects of the Jami Mosque building in detail. Identification of various urban heritage, physical, social and cosmological dimensions of the city and the history of Palopo as the center of Tana Luwu has been done. The background of previous researchers, so far, still minimal, came from the disciplines of architecture.

Reading the void focus of the study is important for the architecture; therefore, the researchers dived to the meaning of identity and symbol of the old mosque building. The scope of this research is meso and micro-scale. Building units as objects, the focus of the study is the meaning and symbols of the Jami Mosque as well as the syntactic relation of the mosque with the surrounding buildings as the core of urban space. 
The purpose of the research is to explore the meaning of the old Palopo mosque. Based on the background and research problem, then the writer formulated the problem of the study as follows: how is the semiotics meaning of the Jami Mosque building in the space center of Palopo City?

\section{CONCEPTION OF AXIS, SPACE, AND MEANING}

History of architecture since ancient Egyptian and Roman times has known about axis and space. Roman architecture is highly dependent and centered on the axis [2]. An axis did exist in Roman architecture that becomes the basic of areas in the building and the open areas of the city. The center, the axis and the space associated with the universe (cosmos), a man understands his place among other human beings, his relationships, nature, and the supernatural world. The natural environment is interpreted from a cultural perspective in traditional cosmology by Dong people in Guangxi Province, China [9]. Natural reflection in the practice of Fengshui is used by Dong people to organize villages, monuments, and vernacular architecture.

The layout in the cities of Southeast Asia is believed based on a cosmological layout consisting of a center with the highest hierarchy, surrounded by circles with a lower hierarchy, and an axis [10]. A layout model like that can be seen as a powerful practice that embodies social hierarchy. It is found in Yogyakarta palace about the cosmological axis as one of the spatial commands of the palace. The north-south axis is visible that passes through the castle which is terminated by two objects as the axis marker and cosmos.

The concept of cosmos by Islamic artists is most likely based on hadiths and Al-Qur'an [11]. The basic concept of the cosmos is analyzed semiotics to reveal symbolic texts that describe the heavenly domain in Sufism tradition. Reading architecture and art in philosophy includes mediating that the art creates space; therefore, architecture forms space and gives freedom to space. The building that is at the heart of the science of architecture should adapt to a living unity and become a goal in itself. Gadamer reinforces architectural relationships with his world, covering more distant subjects as well as shapes till spaces. Hermeneutics and semiotics are two fields of knowledge that complement each other to find meaning. Symbolic Sufism presents the existence of Allah, which is represented by lights and colors and some architectural elements so that Islamic architecture aims to create 'space' for humans to feel the presence of Allah [11].

\section{COSMOLOGY AND ISLAM}

Some specific neo-platonic ideas about the fabric of the universe underlie the efficacy of the sacred place in Islamic cosmology [12]. The essence of god in creating the universe was mediated by prophets who were constantly traversing space and time and were known as 'nur Muhammad.' The nature of the light to enter the divine presence began to be understood by a fairly high spiritual status. The mosque in the middle east, like in Iran, is a place that differentiated and sacred, particularly as specific disclosure from the cosmos model or imagination of heaven. In Europe, particularly in Italy, the mosque is marked by traditional iconography in the form of a dome, tower, and Arabic symbol [13]. The concept of cosmology is in harmony with the concept of traditionalism of an ancient mosque building.

The column of saka guru, the shape of the square floor plan, the theme of symbolism, syncretism, eclecticism, and form symbolism are the indicator of the traditional mosque [14]. Another common characteristic is the roof overlap, tajuq. There is a memolo, which is a rooftop decoration of the concept of Meru Hindu tradition. This concept of Meru Mountain by archaeological researchers was analogous to the concept of axis cosmos or axis mundi in Southeast Asia. Axis mundi in mythology and religion is a place of contact between earth and heaven [15].

Cosmological sciences in traditional Islamic civilization, such as Islamism, are very close to revelation [16]. The study of the cosmos extends to several disciplines (natural scientists, geographers, historians, theologians, philosophers, and tasawwuf). In the classical Islamic civilization that studies dealing with the cosmos within the framework of Islamic cosmology laid the foundation of the teachings on the Qur'an [17]. By following the terminology contained in the Qur'an, there are five gradations of the existence of a world cosmologically; there is only one. The five circumstances are divine (hahut), divine names or universal intelligence (lahut), comprehensible realms or angelic substances (jabarut), psychic realms, or subtle manifestations (malakut) and physical or mortal nature that is dominated by humans (nasut).

Furthermore, in the regularity of the five states of nature in the macrocosm that the essence of hahut lies outside in the analogy of the scheme of a concrete circle. While the symbol microcosm is the opposite. Seyyed Hossein Nasr explicitly reviews the existence of cosmological interpretation in Islam in his dissertation entitled Islamic cosmology, which has the concept of esoteric and exoteric meanings [18].

\section{ETHNOMETHODOLOGY METHOD OF SEMIOTICS PARADIGM}

To reveal the meaning behind the visible sign, then one of the proper ways by approaching the science of signs is semiotics. The effectiveness of the research method with a semiology approach in order to get meaning and concept can decode, fill, shape, and analyze architectural mechanics [19]. Semiotics as a long-used discipline was included in the architecture one of which was used by Charles Jencks. In addition, semiotics get criticism that moves too far from social structure. The development of the semiotics method from interpretative study to interpretive study is meaning based on user community sign [20].

Architectural works that close to art are more objective if the meaning is done by the user 
community and the owner of the sign. The semiotics paradigm with the ethnomethodology method and discourse analysis is one type of qualitative researches [21]. A review of text is included architecture as text to get meaning from others who read it, also called ethno -semiotics. Text, in this case, not only in the form of writing but can also be things, objects, artworks, and even architectural works. The user sign as an informant is social actors such as community leaders, social actors, cultural figures, religious figures, architects, archaeologists, government leaders.

\section{METHODS}

The technique of data analysis was qualitative. In the field study, in addition to conducting in-depth interviews, the researcher also conducted descriptive, focused, and selective observation. Both triangulation techniques and source triangulation have obtained the data. It should be emphasized here that triangulation done by the researcher was triangulation as Stainbeck states that it is not to seek the truth about the existing phenomenon but to increase the researcher's understanding of what was found [22]. This was done because this research does not verify theory but explore the theory, or inductive rather than deductive research.

The data were collected continuously until the data-saturated and could be done in the analysis phase. The data analysis was based on creative power and the researcher's ability. The researcher analyzed the data four times, namely domain analysis, taxonomic analysis, component analysis, and cultural theme analysis. Systematics data analysis referred to Bogdan, i.e., organizing the data, spelling it into units, synthesizing, composing into patterns, choosing which ones were important, and would be learned and then made easy-to-understand conclusions [22]. Furthermore, the researcher examined the validity and reliability data at the end of writing, especially data recorded in in-depth interviews from important informants.

\section{DISCUSSION}

\section{THE ANALOGY OF ISLAMIC TEACHINGS PRE-ISLAM AND} THE ENTRY OF ISLAM

Prior to the entry of Islam, the king and his people believed in the power of the gods including SeuwwaE gods as the only one Sangiang. In local texts (lontara Bugis), the gods are then represented by the letter 'sa' which is shaped like a rhombus. This tendency is in harmony with the gods of ancient Roman civilization. The concept of I La Galigo civilization forms the ideology of godness. If I La Galigo used the term PatotoE as the determinant of destiny, then in Islam, it also believed that what happens in the world is the destiny of god. The entry of Islam directly directed to Tawheed with language hablum minannas and hablum minallah. More than just human relationships with other humans and the individual's relationship to God, but the broader scope of human relationships with nature, human relationships with the supernatural world, and something beyond the reach of human thought and even transcendental. The concept of divinity that has underlaid the kingdom and the community facilitated acceptance of Islam in Luwu. The analogy of alif's physical is different when it is in the sky and on earth. Analogy of the theology of preaching that alif letter when in the sky is 'nun' and when on earth is 'ba.' In harmony with 'Batara Guru' when in the sky, it is referred to as the letter 'nun,' while Batara guru was on earth represented by the letter 'ba.' A philosophical analogy that affirmed the function and essence of something was different when in the sky and on earth. The meaning of Alif as a single substance, and every letter stands alone as a single text; then, the definition refers to the secret of Allah, who is omniscient.

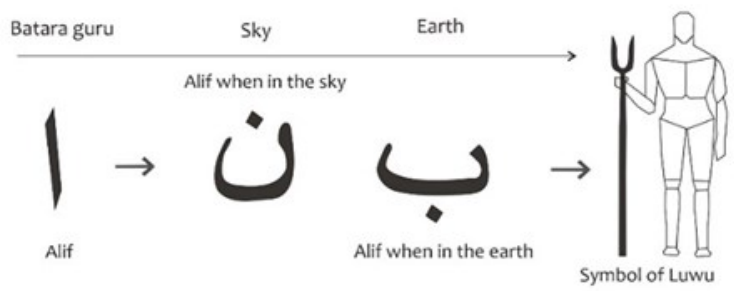

Figure 2. The analogy of Islamic ideology doctrine to Luwu ideology

Between sky and earth are connected by posi bola that pierces up and down like a satay. Posi bola as a symbol of a connector that has meaning whenever and wherever we are, there is always a connection up and down. The deeper philosophical values in every human life cannot be connected with the element of the creator. Posi bola or Soko guru was not only a building structure but also a cosmology signified and a symbol of divinity. In Al-Qur'an Surah Al-Imran; 190 it has been said that there are signs of the creation of the sky and the earth for the intelligent people.

\section{COSMOCENTRIC IN THE POSTMODERN ERA}

The cosmology of Luwu society that made it a high civilization was reflected from the literary work of I La Galigo. Even the customary figure, La Oddang Tosessungriu, called I La Galigo, resembles a religion. Sureq I La Galigo also taught about Tawheed and believed in the one and only god (dewata SeuwwaE). Patterns and systems of the cosmos in Luwu viewed that the universe consists of three layers namely boting langi, ale kawa, and toddang toja or ale lino. Referring to this basic concept was then understood seven layers of the sky; on the top was ale kawa, and the seven stacking down from ale kawa, all of them were called the macrocosm.

Each layer has both tangible and intangible signified as a symbol of the link between upper and lower space. Every human life (microcosm) is always connected with the creator. The knowledge of cosmocentric put Luwu civilization on ancient philosophy. This phase of thought put nature into the object of thought. Nature associated with the creator 
of nature leads to theocentric thought. Between the cosmocentric and theocentric were interconnected to form a magical spiritual culture in Palopo City.

The hierarchy of space consists of the roof, body and foot building is a metaphor of the human body as well as the analogy of the cosmology of Luwu people. The division of space (universe until homestay) represented the understanding of society about the universe - similarly, the building of the mosque, which was originally composed of three parts of space. At the moment, from the floor of the mosque to the underground is still maintained a box hole with a depth of two-meter equipped with security located on the right front corner of the mosque. That's part of the foot of the mosque building that acts as a downstairs.

\section{THE COSMOS AXIS AS A SIGNIFIER OF SPACE TRANSFOR- MATION}

The landscape of the historic city-owned by Palopo city is filled by three important architectural elements in the central part of the city (lalebata), i.e., Jami Mosque, the kingdom palace of Luwu and Marketplace. These three elements were called watampare and based on marowa philosophy. Two important architectural elements of the Jami Mosque have a great relationship in the historical aspect of Islamic civilization and cosmology in Luwu.

Changes in beliefs about the ruler of the universe, followed by changes in the location of the cosmos axis. Since Islam was accepted in Bua, then with Madika Bua facing the Luwu kingdom in Malangke, finally, Luwu kingdom moved to Palopo. In the year $1604 A D$, the entry and acceptance of Islam were marked by the construction of the Jami Mosque which is located in front of Luwu kingdom palace. Since that time, the cosmos axis by kingdom was transferred to the middle pole of the Jami Mosque. Changes in the cosmos axis were based on Luwu's cosmology philosophy.

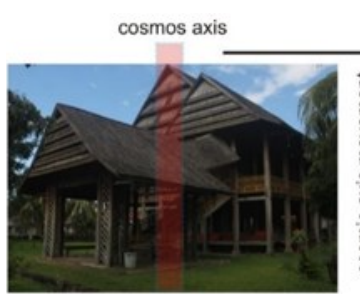

Langkanae palace

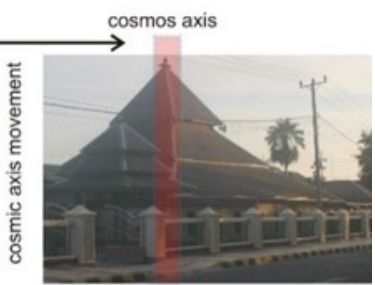

Jami mosque
Figure 3. Space transformation signifiers

The cosmos axis in Luwu is analogous to the boat and water poles. Anton Pangerang in the interview, confirmed that the cosmic axis in Luwu could be moved like a boat sailing position against water. The boat had a mundi axis that could be taken wherever the boat sailed. The more important philosophy is that the axis mundi is not tied to the surrounding world like a boat mast that is not linked to water. Although the Luwu kingdom has undergone location shifts three times in the pre-Islamic era, but it did not affect the cosmos axis because the cosmos axis could move. Likewise, in the period of the entry of Islam, that caused the space transformation. The phenomenon of cosmic axis movement from the palace to the Jami Mosque is analogous to that mosque change boat.

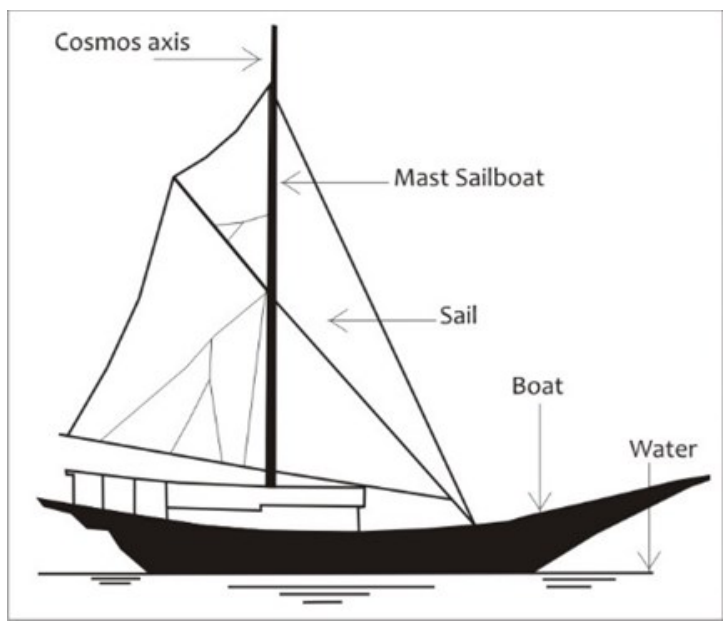

Figure 4. The philosophy of the cosmos axis toward nature

\section{POSI BOLA OF MOSQUE AS A SIGN OF THE COSMOS AXIS}

The middle column (posi bola) of the Jami Mosque has a metaphorical meaning. Various phenomena that occur in the middle pole of the mosque both relation to syntactic, semantic and pragmatic aspects. The syntactic relation related to cinaguri wood material used, it is the same as Luwu kawali grip material. The semantic relation that the pole itself means one of the Islam commandments. The number of wooden poles represents the five Islam commandments as the main structure of the mosque roof cantilever. The centerpiece of the mosque can be a discursive symbol. An analysis of disclosure by sign users was in various disclosure analyzes. In the construction of linguistic logic, symbols will be arranged according to specific syntactic rules that produce a particular reality.

The other metaphorical meaning was the Jami Mosque pole as the center of the intersection of imaginary vertical lines and imaginary horizontal lines. The central point pointed upward as hablum minallah, the individual's relationship to God (through conscience) while horizontally containing at least the human relationships in a social setting as well, courtesy toward nature, and the human relationships with other God's creatures.

The architectural elements did not make visible manifestations of the presence of god. The existence of elements with high aesthetic value was a reflection and contemplation of the great creature processes. The metaphysical dimensions of Islam, cosmology, and philosophy are closely related to geometric proportions [23]. A sacred art shown in the pattern of Islam allows for unlimited semiosis and encourages contemplative reflection. 
Table 1. Display of semiotics meaning

\begin{tabular}{|c|c|c|c|}
\hline \multicolumn{2}{|c|}{ Ethno-Semiotics } & \multirow{2}{*}{ Meaning (3) } & \multirow{2}{*}{ Value (4) } \\
\hline object (1) & referent (2) & & \\
\hline Middle pole mosque & Cosmos axis & Religious symbol & Spirituality \\
\hline & The origin of Palopo's name & $\begin{array}{l}\text { The connector symbols in } \\
\text { the sky and on the earth }\end{array}$ & Obedience \\
\hline 12-angle pole shape & 12-tribes in Luwu & Heterogenity symbol & Unity, brotherhood \\
\hline $\begin{array}{l}\text { The natural material of } \\
\text { columns and walls }\end{array}$ & & & \\
\hline 20 numbers of windows & 20 properties of Allah & Obedience symbol & Religious \\
\hline Roof overlap & Getteng, lempu, adele & $\begin{array}{l}\text { Behaviors that must be } \\
\text { owned by Luwu people }\end{array}$ & $\begin{array}{l}\text { The essence of life } \\
\text { The natural order } \\
\text { (microcosmos) }\end{array}$ \\
\hline Roof shape (macoppo) & $\begin{array}{c}\text { Maha Meru } \\
\text { Iklim tropical climate }\end{array}$ & $\begin{array}{l}\text { Local wisdom } \\
\text { Contextual }\end{array}$ & $\begin{array}{l}\text { Fused with nature } \\
\text { (macro cosmos) }\end{array}$ \\
\hline Letters Nun and $\mathrm{Ba}$ & Sky dan earth & $\begin{array}{l}\text { Differences in function and } \\
\text { meaning }\end{array}$ & Tawheed \\
\hline Jami Palopo Mosque & Town center & Luwu space axis & Space balance \\
\hline Ventilation forms & Turtle (bulus) & $\begin{array}{l}\text { Tawaddu, boast } \\
\text { Hablum minannas }\end{array}$ & $\begin{array}{c}\text { Morals of fellow human } \\
\text { beings }\end{array}$ \\
\hline $\begin{array}{l}\text { Upside-down urn on the } \\
\text { rooftop }\end{array}$ & $\begin{array}{l}\text { Peak structure cover } \\
\text { The entry process of Islam }\end{array}$ & $\begin{array}{c}\text { Symbol Transcendent } \\
\text { symbols } \\
\text { Hablum minalloh }\end{array}$ & Faith \\
\hline
\end{tabular}

\section{TRIBAL REPRESENTATION OF A POLE SHAPE.}

City observers, municipalities, urban communities, and even architects have difficulties in reading the symbols and identity of the city. Palopo is a city that became the center of Luwu civilization, so if you want to design the building of Luwu Raya identity is strived to bring up a sign or symbol that can represent at least twelve tribes in Luwu. Identity can be something tangible that is also intangible. The symbolic interactions of people involved in reading the identity of cities tend to involve heritage objects as part of cultural activities. The categorization of the past, present, and future is to explain the collective memory relations of society.

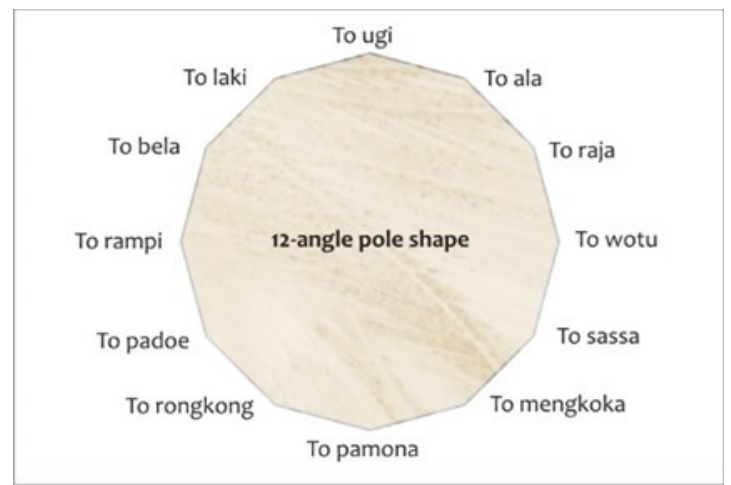

Figure 5. Tribal representation angle in Luwu

Historical review on one side suggested that at the time of middle pole installation of the mosque uttered palopo'i word (insert or plug into the ground). On the other hand, palopo is a typical regional food. The middle column shape represents the number of tribes in Luwu. At least two representations in this phenomenon are tribal representation and representation of the name of Palopo city. As a building structure, the middle pole does not stand alone but with four other poles. Five poles mean connotations as the five commandments of Islam, and as one is of five-day prayer as a commandment of Islam.

\section{FIVE MAIN PILLARS OF THE LIFE PHILOSOPHY}

The structure and construction of buildings in Luwu public figures view do not only serve as a cantilever of building strengthen, but there is also meaning contained in it. Signifiers or objects that appear to have meaning signified. The object of the Jami Mosque was a symbol and the analogy of the number of life philosophies.

The entry process of Islam in the Luwu kingdom has a profound meaning and corresponds to pangadereng Luwu. The five main pillars supporting pangadereng are wari (order), tuppu (harmony), rapang (history), bicara (written law), and Sara (sharia Islam). The concept of sharia being a marker of the entry of Islam because sharia was added when the Kingdom of Luwu embraced Islam. The five unity of the elements were based on two concepts of the singular duality, duae temmasarang, siri na pesse.

Five elements correspond to the five pillars of the Jami Mosque. This analysis was based on the semiological foundation of arbitrary signifiers. Wooden columns that were read as a system of signifiers cannot be separated from the convention system. The religious leader of Jami Mosque, Usman Malla, made the five pillars of the mosque as a symbol of five Islam commandments.

The five cosmological elements of Islam 
correspond to the philosophy of life of pangadereng Luwu. An arbitrary interpretation can be done in semiotics in deconstructing structural meaning. In harmony with Seyyed Hussein Nasr about Islamic cosmology, which refers to how 'humanity transcends.' Five foundations of Islamic cosmology (hahut, lahut, jabarut, malakut, and nasut) lays an understanding of the Jami Mosque in nasut stage.

\section{MEANINGS ON SOME ELEMENTS OF MOSQUE CONSTRUC - TION}

The form follows meaning (pre-modernism era) and function (modernism era), which is extracted by Piliang in his semiotics book is quite relevant to the structure and construction of the Jami Mosque building. Based on the establishment year, Jami Mosque was included in the pre-modernism era. The roof shape of the tajug consists of three layers, rectangular floor plan; the entire wall material was made from natural stone, the pole construction structure and the wooden horses; the number of windows, doors, and ventilation, all of the shape and the amount mentioned store the implicit meaning.

The roof of the mosque is a jar mounted upside down - the function of this ceramic to cover the peak corner of the rainwater leak. The jar substitutes dome in the most mosques generally. The material phenomenon of jars at the top of the mosque is not only in Jami Mosque but also in other mosques use ceramics at the top of the roof of the top layer. In addition to the mosque, Luwu cemetery incorporated in one building which is like a pyramid also paired upside-down jars at the top. Syntactic relation about ceramic jar on the discussion towards the meaning of hermeneutics that jars become a tool to test the power of three datu of preacher Islam. A series of histories in the process of convincing Luwu's kingdom about the glory of Islam, the preacher exposed the power of god through an attraction that was categorized beyond the reach of human thought.
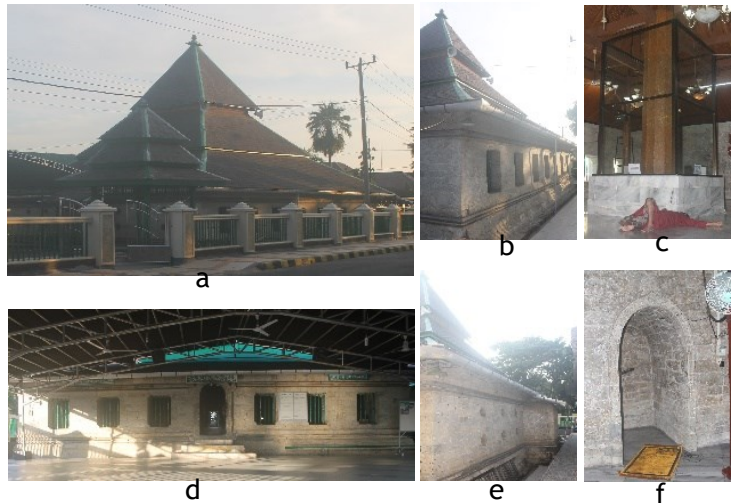

Figure 6. (a) Jami Mosque Perspective (b) Right side (c) Middle pole (d) Front side (e) Back side (f) Mihrab

Overlapping roofs were often associated with other roof typologies in old mosques. Demak Mosque in Java has three roofs. Utilizing the roof shape as a shape of symbolism and ethnic representation was a common strategy applied in Indonesia. Political motivation appeared in the new era suggested the building design has a roof resembling traditional houses. Without aiming to conduct a comparative study, the roof of the Jami Mosque in Palopo has a philosophy at every level. Luwu philosophy consists of three namely getteng (firm), lempu (honest) and adele (fair). Every leader should own this philosophy in Luwu in filling the world as the middle space.

The middle part of the mosque is a wall. Mosque walls are made of natural stone. Wall thickness is 95 $\mathrm{cm}$ on the entire circumference of the mosque building. The selection of materials is not from river stone but mountain rocks because the strength of the mountain stone is considered stronger than the river stone. The stone adhesive is made of lime and egg white mixture. To get lime at that time was easy, i.e., by burning rocks. It is very different from the basic ingredients of cement made from limestone. Windows surrounded the entire wall. The selection of natural material symbolized spiritual building and contextual value. The advancement of mindset to create something new and magnificent (representation of technology and new culture in its era) has existed by the Luwu ancestors proven by the establishment of the Jami mosque.

The windows of the Jami Mosque consist of two types of windows: large windows and small windows (ventilation). There are twenty-large windows. Usman Malla interpreted the number of windows representing the twenty-properties of Allah. Although there are twenty-properties of Allah, only thirteen are known to man. Ventilation mosque applies the bulus (turtle) analogy. The hole forms mimesis empirically with a turtle shape. Turtle is considered to have a awaddu character, which means to bow and not be arrogant. Turtle's behavior after spawning eggs, she did not boast even though she has been spawning in large quantities. In contrast to hen, which has the opposite character of turtles in the context of spawning eggs. Another indication as the metaphorical meaning of turtle-shaped ventilation refers to the architect's background (Fung Man Te) as a descendant of Vietnam that made fauna (natural) forms such as spiders, dragons, and turtles as symbols of life.

Searching identity by making Jami Mosque as a signifier, then the tendency that happens is difficult to be accepted by other ethnic with different religions. Because Luwu consists of at least 12 tribes so that it is difficult to find a concept that can represent everything. The mosque is not the only artifact to display the identity of Islamic architecture. The scope of buildings that manifesting Islamic culture in addition to mosques is the palace, grave, market, fortress, and others, which function as spirituality and expression of the Islamic way of life [24].

\section{CONCLUSION}

The transformation of space in the entry of the Islam era in Palopo city makes posi bola of the Jami Mosque as the cosmos axis and the orientation center 
of Luwu traditions and Islamic culture. The unity of Jami Mosque buildings has represented both Islamic culture and pre-Islamic culture. The architecture of the mosque symbolizes unique, representative, monumental, new, contextual and high Gestalt characters. Exploration of the semiotics meaning of Jami mosque provides fundamental implications in the determination of philosophy and analogy of future architectural design both for Palopo city in particular and for the South Sulawesi region and Indonesia in general. The richness of the meaning of the mosque has implications for the inspiration to search city identity for a concept of heritage preservation and the design of iconic architecture that has become one of the important issues in architectural scholarship in the last decade.

Meanings and symbols for an ancient city are important. Its role in social aspects, cultural tourism, and economic growth is needed. For urban theory as well as architectural developments in the form of landmark elements by Lynch and sign by Sirvani has become a grand theory of arrangement of the built environment. The concept of a new building must be rooted in the philosophy of local wisdom. Palopo city now must learn from the past to create a civilization in the future to become a character city. Space cosmology as a fundamental concept for architecture that its essence is not displaced by the change of religion from pre-Islamic to the entry of Islam. The concept of layers of space that is not contrary to the beliefs of Islamic teachings, but strengthen the faith of universe regularity to conduct further study in the framework of Islamic cosmology and architecture.

\section{REFERENCES}

[1] E. Esfanjary Kenari, "New methodological approaches to the interpretation of historic urban landscapes : the city of Maibud (Iran) as a case study," Ph.D., University of Edinburgh, 2014.

[2] S. Sopandi, Sejarah Arsitektur: Sebuah Pengantar. Jakarta: UPH Press, 2013.

[3] M. I. Mahmud, Kota Kuno Palopo: Dimensi Fisik, Sosial dan Kosmologi. Makassar: Masagena Press, 2003.

[4] C. Buzinde, Y. Choi, and A. Y. Wang, "Tourism Representations of Chinese Cosmology: The Case of Feng Shui Tourism," Ann. Tour. Res., vol. 73, no. 2, pp. 975-996, Apr. 2012.

[5] Iriana, "Fungsi Arajang pada Masyarakat Luwu," Walasuji, vol. o, no. 5, p. 527, Jun. 6459.

[6] F. Surur, "Penataan dan Pelestarian Kawasan Bersejarah Kota Palopo sebagai Kota Pusaka Indonesia," presented at the Temu IImiah IPLBI, 2013.

[7] M. Pabbajah, "Religiusitas dan Kepercayaan masyarakat Bugis- Makassar,” J. Al-Ulum, vol. 56, no. 2, pp. 397-418, 2012.
[8] S. Pawiloy, Ringkasan Sejarah Luwu. Makassar: Telaga Zamzam, 2002.

[9] X. Li, W. Li, K. S. Smith, and A. C. Smith, "Hidden from the wind and enjoying the water (藏风得水) the traditional cosmology of fengshui and the shaping of Dong villages in Southwestern China," Landsc. Res., pp. 1-14, Jun. 2018.

[10] O. Purwani, "Javanese cosmological layout as a political space," Cities, vol. 05, pp. 74-82, Jan. 2017.

[11] N. S. Ramzy, "Visual language in Mamluk architecture: A semiotic analysis of the Funerary Complex of Sultan Qaitbay in Cairo," Front. Archit. Res., vol. 2, no. 3, pp. 338-353, Sep. 2013

[12] S. S. Reese, Imperial Muslims. Edinburgh University Press, 2018.

[13] F. Chiodelli, "Religion and the city: A review on Muslim spatiality in Italian cities," Cities, vol. 88, pp. 19-28, Apr. 2015.

[14] M. S. B. Iskandar, "Tradisionalitas dan Modernitas Tipologi Arsitektur Mesjid," DIMENSI J. Archit. Built Environ., vol. 76, no. 6, pp. 110-118, Dec. 2004.

[15] N. G.-T. Nguyen, "A Study on the Tay Ninh Holy Tower of Caodaism in Vietnam: The Axis Mundi and Cosmic Cross Represented by the Temple," Procedia Eng., vol. 586, pp. 252-259, 2016.

[16] S. H. Nasr, An Introduction to Islamic Cosmological Doctrines. New York: Thames and Hudson, 5312.

[17] Husain Nașr, Science and civilization in Islam. S.I.: ABC International Group, 2001.

[18] M. S. Rahman, "Islam dan Pluralisme," Fikrah, vol. 2, no. 1, Jun. 2014.

[19] M. Parsaee, M. Parva, and B. Karimi, "Space and place concepts analysis based on semiology approach in residential architecture: The case study of traditional city of Bushehr, Iran," HBRC J., vol. 11, no. 3, pp. 368-383, 2015.

[20] Y. A. Piliang, Semiotika dan hipersemiotika: kode, gaya \& matinya makna, Edisi 8. Bandung: Matahari, 2012.

[21] N. K. Denzin and Y. S. Lincoln, Handbook of qualitative research (in indonesia). Yogyakarta: Pustaka Pelajar, 2009.

[22] Sugiyono, Metode Penelitian Kuantitatif, Kualitatif dan R \& D. Bandung: Alfabeta, 6455.

[23] L. M. Dabbour, "Geometric proportions: The underlying structure of design process for Islamic geometric patterns," Front. Archit. Res., vol. 5, no. 4, pp. 380-391, 2012.

[24] W. S. Sahabuddin, "Dome Form Typology Of Islamic Architecture In Persia," J. Islam. Archit., vol. 4, no. 4, p. 163, Dec. 2017. 